\title{
Gambaran Kesehatan Mental Emosional Siswa SMA Tahun 2020 Menggunakan Strengths and Difficulties Questionnaire
}

\author{
Nadya Alexia Iskandar' ${ }^{1}$ Elly Ingkiriwang², Elly Tania ${ }^{2}$ \\ ${ }^{1}$ Fakultas Kedokteran dan Ilmu Kesehatan, Universitas Kristen Krida Wacana, Jakarta, Indonesia \\ ${ }^{2}$ Departemen Psikiatri, Fakultas Kedokteran dan Ilmu Kesehatan, Universitas Kristen Krida Wacana, Jakarta, \\ Indonesia \\ Alamat Korespondensi: nadya.2017fk160@civitas.ukrida.ac.id
}

\begin{abstract}
Abstrak
Di Indonesia, sekolah-sekolah senantiasa berusaha meningkatkan mutu pendidikan yang ada dengan menciptakan sistem pendidikan terbaik bagi para siswanya. Terdapat berbagai sekolah unggulan yang memiliki prestasi akademis maupun non-akademis yang menonjol dalam skala nasional maupun internasional. Namun, siswa di sekolah unggulan juga tidak luput sebagai kelompok yang rentan untuk mengalami gangguan mental emosional seperti stres, depresi, kecemasan, atau gejala somatik. Oleh karena itu, penelitian dilakukan berupa desain penelitian deskriptif dengan pendekatan cross-sectional menggunakan Strengths and Difficulties Questionnaire untuk mengetahui skor masalah emosi dan perilaku pada siswa di sekolah unggulan. Berdasarkan hasil penelitian dari kuesioner yang disebarkan diperoleh data 68 responden siswa SMA Negeri 78 Jakarta yang merupakan salah satu sekolah unggulan, terdapat 28 responden (41\%) yang memiliki skor kesulitan di atas batas normal, dimana berarti skor mental emosional serta perilakunya berada dalam kategori borderline (skor perbatasan) dan abnormal (skor tinggi). Hal ini tidak lepas dari adanya peran orangtua, keluarga, teman sebaya, dan lingkungan sekitarnya. Sebagai contoh penghasilan keluarga, status perkawinan orangtua, pola asuh orangtua, urutan kelahiran anak, bullying di sekolah, prestasi yang diraih, jarak sekolah, durasi penggunaan media sosial setiap harinya, serta kendala online learning selama pandemi. Faktor-faktor tersebut dapat mempengaruhi kesehatan mental, emosi, dan perilaku siswa, tak terkecuali di sekolah unggulan.
\end{abstract}

Kata Kunci: emosi, mental, sekolah unggulan, SMA, strengths and difficulties questionnaire

\section{Description of Emotional Mental Health of High School Students in 2020 Using Strengths and Difficulties Questionnaire}

\begin{abstract}
In general, schools always try to improve the quality of their education by creating the best education system delivered to their students. There are various excellent schools that have outstanding academic and nonacademic achievements on a national and international scales. However, students in top schools are also vulnerable to experiencing mental and emotional disorders such as stress, depression, anxiety, or somatic symptoms. The aim of this research was to evaluate emotion and behavior of the students at top school. Therefore, the research was conducted in the form of a descriptive research design with a cross-sectional approach. The Strengths and Difficulties Questionnaire was used to determine the score of emotional and behavioral problems among students. Participants in this study was students of SMA Negeri 78 Jakarta which is one of the leading schools in Jakarta. Among 68 respondents, there were 28 respondents (41\%) who had a difficulty score above the normal limit, indicating that their mental emotional score and their behavior were in the category of borderline (border score) and abnormal (high score). This cannot be separated from the role of parents, family, peers, and their environment. Factors identified to affect the studets were working parents, family income, parental marital status, parenting styles, child birth order, bullying at school, achievements, school distance, daily use of social media, and online learning constraints during the pandemic. These factors can affect mental health, emotions, and behavior of students, including in superior schools.
\end{abstract}

Keywords: emotions, mental, senior high school, strengths and difficulties questionnaire, top school 


\section{Pendahuluan}

Di Indonesia, pendidikan telah menjadi prioritas dalam mencetak sumber daya manusia yang berkualitas. Sekolah-sekolah di Indonesia senantiasa berusaha meningkatkan mutu pendidikan yang ada dengan menciptakan sistem pendidikan terbaik yang dapat disalurkan kepada siswa-siswinya. Dari usaha yang diberikan tersebut, tentunya terdapat sekolah-sekolah unggulan yang memiliki prestasi akademis maupun non-akademis yang menonjol dalam skala nasional maupun internasional. Siswa-siswi tentunya berlomba-lomba untuk mengemban pendidikan di sekolah-sekolah unggulan tersebut, bahkan sedari Sekolah Menengah Pertama (SMP) sampai universitas unggulan. ${ }^{1,2}$ Hal ini tentu sangatlah positif mengingat sekolah unggulan akan meningkatkan kemungkinan untuk menciptakan individu yang berkualitas dan mampu bersaing di dalam perkembangan revolusi industri. ${ }^{1}$

Sekolah-sekolah unggulan tersebut tentunya akan terus mempertahankan prestasi para siswasiswinya dari waktu ke waktu, sehingga secara tidak langsung sekolah-sekolah unggulan tersebut memiliki tuntutan akademik yang lebih besar kepada siswa-siswinya dibandingkan sekolah lainnya. ${ }^{1}$ Selain itu, siswa-siswi juga harus menghadapi persaingan yang kompetitif antar siswa dengan harapan dapat menjadi yang terbaik di sekolah unggulan yang bersangkutan. ${ }^{1,2}$ Beberapa penelitian menyatakan bahwa siswa di sekolah unggulan memiliki insiden yang jauh lebih tinggi untuk mengalami stres, depresi, kecemasan, gejala somatik, kecenderungan untuk melanggar peraturan atau kenakalan remaja, bahkan penyalahgunaan obat terlarang dan alkohol bila dibandingkan dengan sekolah lainnya., ${ }^{1,4}$ Berdasarkan hasil penelitian, ditemukan bahwa prevalensi tingkat kecemasan, depresi, dan gejala somatik (seperti sakit kepala dan sakit perut yang tidak berkaitan dengan masalah kesehatan fisik) di sekolah unggulan yang berada di Amerika Serikat sebesar $20 \% .^{1}$ Namun, terdapat pula studi yang telah dilakukan di Hong Kong menunjukkan bahwa siswa yang berprestasi tidak mempunyai gejala gangguan mental emosional dan perilaku sama sekali dibandingkan yang tidak berprestasi, serta cenderung memiliki tingkat kepuasan hidup yang lebih tinggi sesuai dengan meningkatnya prestasi mereka di sekolah. ${ }^{5}$ Tentunya terdapat perbedaan kebudayaan yang dianut antara negara Asia dan Barat. ${ }^{6}$

Berdasarkan uraian diatas maka perlunya dilakukan penelitian lebih jauh mengenai gambaran tingkat masalah emosi dan perilaku siswa di sekolah unggulan. Salah satu cara yang sudah diakui untuk menilai masalah dan kekuatan pada anak adalah melalui kuesioner Strengths and Difficulties Questionnaire untuk mengetahui masalah yang berhubungan dengan emosional dan perilaku pada remaja yang akan diisi oleh siswa Sekolah Menengah Atas unggulan. Dipilihnya SMA Negeri 78 Jakarta yang berlatar sebagai salah satu sekolah unggulan di Indonesia, khususnya Jakarta.

\section{Metodologi}

Penelitan yang akan dilakukan merupakan observasi deskriptif dengan pendekatan kuantitatif cross sectional. Dalam studi ini, peneliti hendak menggambarkan skor Strengths and Difficulties Questionnaire siswa Sekolah Menengah Atas unggulan di SMA Negeri 78 Jakarta. Penelitian ini menggunakan nomor kaji etik 962/SLKEIM/UKKW/FKIK/KE/VII/2020. Informed consent dilakukan pada kedua pihak yaitu guru dan siswa sebelum dimulai melakukan penelitian.

Jumlah sampel yang diambil adalah 68 siswa kelas XI SMA Negeri 78 Jakarta. Kriteria inklusi pada penelitian ini adalah siswa kelas XI SMA Negeri 78 Jakarta, berusia 15-16 tahun, dan telah disetujui oleh orangtua atau wali. Sedangkan untuk kriteria eksklusi yaitu siswa yang tidak memiliki koneksi internet yang memadai pada waktu pengisian kuesioner berlangsung. Penelitian ini dilakukan pada siswa kelas XI dikarenakan umur siswa kelas XI yang memenuhi kriteria untuk mengisi Strengths and Difficulties Questionnaire, yaitu berkisar antara umur 15-16 tahun.

Alat pengumpulan data yang akan digunakan dalam penelitian ini adalah kuesioner. Adapun variabel-variabel yang diukur antara lain jenis kelamin, usia, orangtua yang bekerja, status perkawinan orangtua, pendapatan keluarga, pola asuh orangtua, urutan kelahiran anak, bullying di sekolah, jarak sekolah, prestasi yang diraih, penggunaan media sosial, serta kendala online learning selama pandemi dengan menggunakan kuesioner. Pada penelitian ini peneliti menggunakan Strengths and Difficulties Questionnaire yang sudah dikenal luas dalam mendeteksi dini adanya masalah mental emosional dan perilaku pada anak dan remaja yang berusia 316 tahun di dunia dan Indonesia. Kuesioner yang disebarkan berisi daftar pertanyaan untuk mengetahui tingkat mental dan emosi remaja dan sudah tervalidasi dalam berbagai bahasa di dunia, termasuk Bahasa Indonesia. 
Data yang diperoleh melalui kuesioner yang telah dibagikan secara online kepada siswa kelas XI SMA Negeri 78 Jakarta akan disajikan dalam bentuk tabel dan narasi. Pada penelitian ini, peneliti melakukan uji analisis univariat untuk menggambarkan distribusi dan frekuensi dari masing-masing variabel bebas dan terikat dengan bantuan program Statistical Package for the Social Sciences (SPSS) versi 23.

\section{Hasil Penelitian}

Usia responden pada Sekolah Menengah Atas Negeri 78 Jakarta kelas XI adalah berkisar antara usia 15 sampai 16 tahun, dengan mayoritas siswa berusia 16 tahun. Persebaran jenis kelamin responden yang diteliti lebih banyak siswa perempuan $(72,1 \%)$ dibanding siswa laki-laki di sekolah tersebut $(27,9 \%)$.

Orangtua yang bekerja diklasifikasikan berdasar kedua orangtua yang bekerja, ayah yang bekerja, ibu yang bekerja, tidak bekerja atau pensiun. Tabel distribusi frekuensi menunjukkan mayoritas orangtua responden yang bekerja adalah ayah sebagai tulang punggung keluarga. Rata-rata status perkawinan orangtua responden yaitu bukan single parent yang berarti memiliki kedua orangtua yang lengkap. Status ekonomi keluarga diklasifikasikan berdasar jumlah penghasilan keluarga per bulan, dengan ketentuan dibawah 5 juta rupiah rendah, 5 juta sampai 10 juta rupiah menengah, 10 juta rupiah tinggi. Tabel distribusi frekuensi menunjukkan mayoritas responden berasal dari keluarga dengan status ekonomi menengah ke atas.

Siswa SMAN 78 Jakarta kelas XI memiliki pola asuh orangtua yang berbeda-beda, dimana sebanyak 26 responden $(37,7 \%)$ menyatakan orangtuanya menggunakan pola asuh otoritatif, 22 responden $(33,3 \%)$ menyatakan pola asuh permisif, 18 responden $(26,1 \%)$ menyatakan pola asuh otoriter, dan 2 responden $(2,9 \%)$ menyatakan pola asuh tidak terlibat.

Urutan kelahiran di keluarga responden juga bervariasi, terdapat 1 responden $(1,4 \%)$ yang merupakan anak tunggal, 27 responden $(39,1 \%)$ anak pertama, 21 responden $(31,9 \%)$ anak kedua, 15 responden $(21,7 \%)$ anak ketiga, 2 responden $(2,9 \%)$ anak keempat, 1 responden $(1,4 \%)$ anak keenam, dan 1 responden $(1,4 \%)$ yang kembar.

Jumlah orang yang ditanggung oleh kepala keluarga berpengaruh terhadap status sosial keluarga mereka, jika kepala keluarga memiliki penghasilan 4 juta rupiah dan banyak anggota keluarga yang ditanggung hanya tiga orang, tentunya masalah ekonomi mereka akan lebih baik dibandingkan dengan kepala keluarga yang mendapatkan penghasilan 6 juta rupiah dengan banyaknya anggota keluarga yang ditanggung adalah enam orang. Namun pada penelitian ini, jumlah anak yang ditanggung oleh orangtua di SMAN 78 Jakarta kelas XI kurang lebih tidak berbeda jauh.

Sebagian besar siswa kelas XI di SMAN 78 Jakarta tidak pernah dibully atau melakukan tindakan bullying di sekolah, baik secara verbal ataupun non verbal. Namun, terdapat 4 siswa yang pernah menjadi korban bullying, bahkan 11 responden mengaku pernah menjadi pelaku dari tindakan bullying itu sendiri.

Mayoritas siswa SMAN 78 Jakarta tinggal dengan jarak lebih dari $5 \mathrm{~km}$ dari sekolahnya, meskipun terdapat beberapa yang tempat tinggalnya sangat dekat, yaitu kurang dari $3 \mathrm{~km}$. Dari seluruh responden hanya ada sebagian yang merupakan juara kelas, sementara yang lainnya tidak juara.

Rata-rata lama waktu yang dihabiskan responden selama bermain media sosial setiap harinya adalah berkisar antara $>3$ jam- $\leq 6$ jam, meskipun tidak ada perbedaan yang cukup jauh antara responden lainnya yang bermain selama $>6$ jam. Terdapat pula satu responden yang tidak memiliki media sosial.

Selama pandemi COVID-19 berlangsung kegiatan belajar mengajar di sekolah digantikan dengan online learning atau belajar di rumah secara daring, siswa SMAN 78 Jakarta kelas XI mempunyai kendala masing-masing yang berbeda, dengan sebagian besar responden memiliki paling sedikit 1 kendala yang dihadapi.

Tabel 1. Distribusi Skor Kekuatan (Prosocial Behaviour Score) dan Kesulitan (Total Difficulties Score) Responden Penelitian

\begin{tabular}{lc}
\hline Interpretasi Skor SDQ & $\begin{array}{c}\text { Jumlah Responden } \\
(\boldsymbol{\%})\end{array}$ \\
\hline Skor Kekuatan & $63(92,6)$ \\
Normal & $5(7,4)$ \\
Borderline & $0(0)$ \\
Abnormal & \\
Skor Kesulitan & $40(58,8)$ \\
Normal & $14(20,6)$ \\
Borderline & $14(20,6)$ \\
Abnormal & \\
\hline
\end{tabular}

Berdasarkan data pada tabel 1 di atas menunjukkan bahwa diantara 68 responden, didapatkan pada skor kekuatan, 5 anak memiliki 
skor yang cukup tinggi, yaitu dalam kategori borderline, serta tidak ditemukan skor yang abnormal. Sedangkan untuk skor kesulitan terdapat 14 anak yang berada pada borderline, 14 anak mempunyai skor yang tinggi sehingga masuk dalam kategori abnormal, dan yang lainnya normal.

Pada skor kesulitan, terdapat 14 responden yang termasuk dalam kategori borderline dan 14 responden dalam kategori abnormal. Di antara 14 siswa yang memiliki skor borderline, terdiri dari 10 perempuan dan 4 laki-laki yang usianya tidak berbeda jauh, yaitu 13 anak berusia 16 tahun dan 1 anak berusia 15 tahun dengan jurusan kelas yang bervariasi, 9 anak mengambil jurusan IPA, 3 anak jurusan IPS, dan 2 anak jurusan Bahasa. Sedangkan untuk 14 anak yang mendapatkan skor abnormal, selanjutnya terbagi menjadi 13 perempuan dan 1 laki-laki dengan rentang usia yang hampir sama, yaitu 13 anak berusia 16 tahun dan 1 berusia 15 tahun, dimana 8 siswa berada di jurusan IPA, 5 siswa jurusan IPS, dan 1 siswa jurusan Bahasa.

Pada anak yang borderline, ada 8 orang yang ayahnya bekerja, 4 orang merupakan ibunya yang bekerja, dan 2 orang yang kedua orangtuanya bekerja dengan penghasilan yang berbeda-beda, yaitu 7 anak menyatakan penghasilan keluarga setiap bulannya berjumlah <Rp.5.000.000,-, 4 anak dengan berpenghasilan keluarga menengah Rp. 5.000.000,- - 10.000.000,-, dan 3 anak lain sebesar Rp. >10.000.000,-. Terdapat 4 responden yang kepala keluarganya menanggung sebanyak 2 orang, 5 responden sebanyak 3 orang, 4 responden sebanyak 4 orang, dan 1 responden sebanyak 5 orang.

Dari anak yang skornya abnormal, didapatkan 9 anak merupakan ayah yang bekerja sebagai tulang punggung keluarga, 4 anak adalah kedua orangtuanya yang bekerja, dan 1 anak orangtuanya tidak bekerja atau sudah pensiun dengan penghasilan keluarga yang bervariasi, sebanyak 4 siswa menyatakan penghasilan keluarga setiap bulannya adalah $<$ Rp.5.000.000,-, 6 siswa dengan penghasilan keluarga Rp. 5.000.000,- 10.000.000,-, dan 4 siswa dengan jumlah penghasilan keluarga yang tinggi Rp. $>10.000 .000,-$. Ada 1 anak yang kepala keluarganya menanggung sebanyak 2 orang, 2 anak sebanyak 3 orang, 6 anak sebanyak 4 orang, 3 anak sebanyak 5 orang, dan 2 anak sebanyak 6 orang.

Berdasarkan hasil penelitian diatas, dapat dilihat bahwa anak yang memiliki skor borderline dan abnormal cenderung merupakan ayahnya yang bekerja sebagai tulang punggung keluarga sehingga hal ini tidak sesuai dengan penelitian Ogundele et al. (2018) yang menyatakan bahwa keluarga yang kedua orangtuanya bekerja dapat memberikan pengaruh yang buruk pada kesehatan mental emosional remaja. ${ }^{7}$ Terdapat penelitian Lorraine et al. (2017) yang menunjukkan bahwa ayah turut berperan dalam perkembangan mental emosional dan perilaku anak. Semakin dekat hubungan ayah dan anak, maka akan mengurangi risiko terjadinya masalah perilaku pada anak lakilaki dan masalah psikologis pada anak perempuan, hubungan antar sesama yang lebih baik, serta meningkatkan kepuasan hidup, baik pada anak laki-laki maupun perempuan. ${ }^{8}$

Beberapa hasil penelitian juga menunjukkan penghasilan keluarga berpengaruh dalam mental emosional remaja, yaitu remaja yang berada pada keluarga yang penghasilannya lebih rendah mempunyai kecenderungan untuk mengalami depresi yang lebih besar. Hal tersebut tidak sesuai dengan penelitian ini, dimana remaja yang mempunyai skor borderline adalah yang penghasilan keluarganya rendah yaitu $<\mathrm{Rp}$. 5.000 .000 ,- dan pada remaja dengan skor abnormal penghasilan keluarganya termasuk dalam klasifikasi menengah yaitu Rp. 5.000.000,- 10.000.000,-. ${ }^{9} 10$ Terdapat penelitian Suniya et al. (2013) menyatakan bahwa anak yang berada di keluarga yang berpenghasilan menengah ke atas juga berisiko dalam mengalami gangguan mental emosional internalisasi dan eksternalisasi, penyalahgunaan alkohol dan obat terlarang, dimana umumnya ketika memasuki usia remaja, yang meminta kebebasan kepada orangtuanya. Pada orangtua yang tingkat sosial ekonominya cukup tinggi ini akan memberikan kebebasan tanpa penjagaan, dengan memercayai konsep anaknya aman karena berada pada lingkungan yang baik dan sekolah yang bagus. ${ }^{2}$

Status perkawinan orangtua 14 responden yang memiliki skor borderline, didapatkan 13 responden mempunyai kedua orangtua yang lengkap (bukan single parent) dan 1 responden mempunyai orangtua tunggal atau single parent. Sebanyak 6 anak merasa pola asuh orangtuanya adalah otoritatif, 4 anak merasa pola asuh otoriter, dan 4 anak merasa pola asuh permisif. Dari urutan kelahiran keluarga, terdapat 7 anak yang merupakan anak urutan pertama, 3 anak adalah anak kedua, 3 anak adalah anak ketiga, dan 1 anak adalah anak tunggal.

Sedangkan pada 14 siswa lainnya yang memiliki skor abnormal, 12 siswa memiliki kedua orangtua yang lengkap dan 2 siswa lainnya 
memiliki orangtua tunggal. Sebanyak 6 anak merasakan pola asuh orangtuanya adalah otoritatif, 4 anak merasa pola asuh otoriter, 3 anak merasa pola asuh permisif, dan 1 anak merasakan pola asuh tidak terlibat, dimana kehangatan orangtua rendah dan kontrol orangtua rendah. Dari urutan kelahiran keluarga, ada 4 anak yang merupakan anak urutan pertama, 4 anak adalah anak kedua, 4 anak adalah anak ketiga, dan 2 anak adalah anak keempat.

Dari hasil penelitian diatas, didapatkan bahwa remaja yang memiliki skor borderline dan abnormal cenderung adalah yang memiliki kedua orangtua lengkap, namun dari 4 remaja yang orangtuanya merupakan single parent, 3 diantaranya memiliki skor borderline dan abnormal sehingga hal ini sesuai dengan beberapa hasil studi yang menyatakan bahwa orangtua yang bercerai atau berpisah (single parent) mempengaruhi remaja dalam mengalami gangguan mental emosional..$^{7,10}$

Penelitian ini juga memberikan hasil bahwa responden yang mendapatkan skor borderline dan abnormal cenderung pola asuh orangtuanya adalah otoritatif, yang berarti tidak sesuai dengan beberapa penelitian sebelumnya yang menunjukkan pola asuh otoritatif mengurangi terjadinya gangguan mental emosional internalisasi seperti depresi dan kecemasan, meningkatkan kesehatan mental remaja, mengurangi masalah perilaku eksternalisasi pada remaja seperti tidak patuh pada aturan sekolah dan membolos, mengonsumsi minuman keras, serta meminimalkan terjadinya stres yang dapat berdampak pada gejala somatik. ${ }^{11-14}$ Penelitian Joan et al. (2010) menyatakan bahwa pola asuh otoritatif adalah pola asuh orangtua yang paling baik dalam mengurangi terjadinya gangguan mental emosional internalisasi dan eksternalisasi pada remaja, namun juga tidak luput dari adanya kemungkinan sang anak mengalami depresi dalam proses perkembangannya. ${ }^{15}$

Pada penelitian yang telah dilakukan ini juga diketahui siswa yang mempunyai skor borderline dan abnormal cenderung merupakan anak pertama, sehingga hal ini tidak sesuai dengan beberapa hasil studi yang menyatakan bahwa anak bungsu atau anak yang paling muda di keluarga meningkatkan risiko terjadinya percobaan bunuh diri dan gangguan mental yang dialami remaja, terkait dengan adanya bullying yang dapat dilakukan oleh saudara-saudaranya yang lebih tua terhadap yang lebih muda sehingga dapat menyebabkan gangguan mental emosional seperti depresi, kecemasan, tindakan melukai diri sendiri, serta dapat dipengaruhi oleh perubahan sosial ekonomi keluarga yang terjadi setelah kelahiran anak bungsu tersebut. ${ }^{16-18}$ Terdapat pula beberapa penelitian yang menunjukkan bahwa anak pertama lebih berisiko untuk mengalami depresi dan kecemasan dibandingkan anak yang lahir setelahnya karena orangtua cenderung akan terlalu protektif terhadap anak sulung, namun ini tidak jauh berbeda dengan kecenderungan yang dapat dialami oleh anak bungsu. ${ }^{19,20}$

Diantara 14 remaja yang berada pada kategori borderline, 12 remaja mengaku tidak pernah dibully atau melakukan tindakan bullying di sekolah, satu remaja pernah melakukan tindakan bullying, dan satu remaja lainnya pernah menjadi korban bullying. Ada 1 orang yang merupakan juara kelas tiga besar, 1 orang juara kelas lima besar, 4 orang juara kelas sepuluh besar, dan 8 anak lain tidak juara kelas. Sebanyak 4 anak tinggal dengan jarak cukup dekat dari sekolahnya yaitu $\leq 3$ $\mathrm{km}, 3$ anak tinggal dengan jarak $>3 \mathrm{~km}-<5 \mathrm{~km}$, dan 7 anak lainnya tinggal dengan jarak sejauh $>5$ $\mathrm{km}$.

Pada 14 responden lain yang masuk pada kategori abnormal, 11 responden menyatakan tidak pernah dibully atau melakukan tindakan bullying di sekolah, 2 responden pernah melakukan tindakan bullying, dan 1 responden pernah menjadi korban bullying. Terdapat 2 siswa yang merupakan juara kelas tiga besar, 2 siswa yang juara kelas lima besar, 3 siswa yang juara kelas sepuluh besar, dan 7 lainnya tidak juara kelas. Sebanyak 8 anak tinggal dengan jarak $\leq 3 \mathrm{~km}$ dari sekolahnya, 1 anak tinggal dengan jarak menengah $>3 \mathrm{~km}-<5$ $\mathrm{km}$, dan 5 anak lainnya tinggal dengan jarak $>5$ $\mathrm{km}$.

Berdasarkan penelitian ini didapatkan hasil remaja yang mendapatkan skor borderline dan abnormal cenderung adalah yang tidak pernah dibully atau melakukan tindakan bullying di sekolah sehingga hal ini tidak sesuai dengan beberapa penelitian yang sudah dilakukan sebelumnya bahwa bullying berpengaruh pada gangguan kecemasan dan depresi pada remaja. ${ }^{21,22,23}$ Dimana korban bullying mengalami tingkat depresi dan kecemasan yang lebih tinggi, meningkatkan risiko menurunnya harga diri, serta kesulitan dalam membangun dan mempertahankan hubungan dengan orang lain. ${ }^{21}$

Terdapat penelitian Andre et al. (2015) di Finlandia yang menemukan bahwa sebagian besar anak yang datang ke poliklinik jiwa atau sebanyak $90 \%$ dari responden yang tidak terlibat dalam bullying, tetapi sekitar $20 \%$ diantaranya pernah menjadi pelaku tindakan bullying saat masih anak- 
anak memiliki masalah kesehatan mental yang membutuhkan perawatan medis saat remaja atau dewasa muda dan $23 \%$ dari anak-anak yang sering menjadi korban bullying telah mencari bantuan untuk gangguan mental yang dihadapinya sebelum memasuki usia dewasa. ${ }^{24}$

Penelitian diatas juga diketahui memberikan hasil bahwa siswa yang mempunyai skor borderline cenderung adalah yang tidak juara kelas dan pada siswa yang skornya abnormal tidak ada perbedaan antara yang juara dan tidak juara kelas atau terbagi rata sehingga hal tersebut tidak sesuai dengan penelitian Shek et al. (2016) yang menunjukkan bahwa siswa yang berprestasi tidak mempunyai gejala gangguan mental emosional dan perilaku sama sekali dibandingkan yang tidak berprestasi, serta cenderung memiliki tingkat kepuasan hidup yang lebih tinggi sesuai dengan meningkatnya prestasinya di sekolah. ${ }^{5}$ Beberapa penelitian menyatakan bahwa siswa berprestasi tidak luput dari gangguan mental emosional karena adanya persaingan dan perbandingan nilai antar siswa pada pelajaran di sekolah, baik intra dan ekstrakurikuler, terutama di sekolah unggulan. ${ }^{1,9}$ Hubungan antar teman sebaya yang kompetitif secara terus-menerus untuk menjadi yang terbaik diantara temannya dapat membuat remaja menjadi stres dan mengalami gangguan kecemasan. ${ }^{9}$

Pada hasil penelitian ini didapatkan pula pada responden yang memiliki skor borderline cenderung tinggal dengan jarak dari rumah ke sekolah sejauh $>5 \mathrm{~km}$ dan responden yang abnormal pada jarak yang cukup dekat yaitu $\leq 3 \mathrm{~km}$ sehingga hal tersebut tidak sesuai dengan beberapa penelitian yang menyatakan bahwa jarak antara sekolah dan tempat tinggal siswa berpengaruh buruk pada kesehatan mental remaja. Semakin jauh jarak yang ditempuh dari rumah ke sekolah akan mengurangi waktu tidur siswa dan meningkatkan risiko terjadinya penurunan konsentrasi belajar di sekolah sehingga siswa lebih rentan untuk mengalami stres dan depresi. ${ }^{25-27}$ Terdapat beberapa hasil studi yang menunjukkan bahwa pada masa sekarang ini, remaja seringkali tidak mendapatkan waktu tidur yang cukup, terutama pada siswa sekolah menengah atas. Hal ini dapat dipengaruhi oleh berbagai faktor, seperti gaya hidup yang modern, dimana terjadi peningkatan penggunaan teknologi sebelum tidur, serta faktor biologis yaitu adanya perubahan awal yang berkaitan dengan pubertas, dimana terdapat perubahan ritme sirkadian pada remaja sehingga lebih terjaga pada sore dan malam hari, bahkan hingga pukul 11 malam atau lebih, meskipun telah mencoba untuk tidur lebih awal..$^{28-30}$
Pada 14 remaja dengan skor borderline, didapatkan bahwa 1 remaja bermain media sosial selama $\leq 30$ menit setiap harinya, 3 remaja selama $>30$ menit $-\leq 3$ jam, 4 remaja selama $>3$ jam $-\leq 6$ jam, dan 6 remaja selama $>6$ jam. Sementara pada remaja dengan skor abnormal, terdapat 1 remaja yang bermain selama $>30$ menit- $\leq 3$ jam, 7 remaja selama $>3$ jam- $\leq 6$ jam, dan 6 remaja selama $>6$ jam. Berdasarkan hasil penelitian ini, dapat dilihat bahwa remaja yang memiliki skor borderline dan abnormal merupakan remaja yang bermain sosial media selama $>3$ jam- $\leq 6$ jam. Hal tersebut adalah benar dan sesuai dengan beberapa hasil studi yang menunjukkan bahwa media sosial dapat memberikan pengaruh negatif pada mental emosional dan perilaku remaja. Remaja yang menggunakan sosial media selama 3 jam setiap harinya berisiko untuk mengalami gangguan depresi dan kecemasan, dan jika digunakan selama 6 jam maka risiko akan jauh lebih tinggi. ${ }^{31-34}$

Kendala yang dihadapi selama online learning karena pandemi COVID-19 oleh siswa dengan skor borderline dan abnormal juga berbeda-beda. Pada 14 siswa yang mempunyai skor borderline, 6 siswa mengalami 1 kendala, 5 siswa mengalami 2 kendala, dan 3 siswa mengalami 3 kendala. Dari 14 siswa lainnya yang berada dalam kategori abnormal, sebanyak 5 siswa menghadapi 1 kendala, 5 siswa menghadapi 2 kendala, dan 4 siswa mengalami 3 kendala.

Pada hasil penelitian diatas, siswa yang mempunyai skor borderline dan abnormal cenderung hanya mengalami 1 kendala selama online learning dan tidak berpengaruh pada mental emosionalnya. Hal ini tidak sesuai dengan beberapa hasil studi yang menyatakan bahwa ketika siswa belajar di rumah dengan sumber daya dan alat online yang terbatas, timbulnya ketidakmampuan siswa untuk mengontrol diri sendiri, menunda tugas dan pekerjaan rumah yang diberikan sekolah, tidak mau tidur tepat waktu, tidak tertarik untuk belajar, kecanduan perangkat elektronik (ponsel, tablet, dan lain-lain), serta kecemasan akan tidak memahami materi pembelajaran, terutama untuk siswa yang akan lulus dari sekolah. ${ }^{35,36}$ Terdapat penelitian Jorg et al. (2020) yang menemukan bahwa online learning selama pandemi juga mempunyai kelebihannya tersendiri, seperti lebih banyak waktu luang yang dapat dinikmati bersama keluarga sehingga dapat mempererat dan memperkuat hubungan dengan anggota keluarga, serta anak yang mengalami permasalahan di sekolah seperti bullying juga dapat merasakan situasi sekolah yang aman dan 
tenang di rumah yang berpengaruh pada mental emosional siswa. ${ }^{37}$

Tabel 2. Distribusi Masalah Mental Emosional Responden Penelitian

\begin{tabular}{ll}
\hline $\begin{array}{l}\text { Total Skor Kesulitan } \\
\text { (Total Difficulties Score) }\end{array}$ & $\begin{array}{c}\text { Jumlah } \\
\text { Responden } \\
(\%)\end{array}$ \\
\hline Gejala Emosional & $35(51,4)$ \\
$\quad$ Normal & $11(16,2)$ \\
Borderline & $22(32,4)$ \\
Abnormal & \\
Masalah Perilaku & $54(79,4)$ \\
Normal & $10(14,7)$ \\
Borderline & $4(5,9)$ \\
Abnormal & \\
Hiperaktivitas & $46(67,6)$ \\
Normal & $16(23,5)$ \\
Borderline & $6(8,9)$ \\
Abnormal & \\
Masalah hubungan & \\
dengan teman sebaya & \\
Normal & $57(83,8)$ \\
Borderline & $10(14,7)$ \\
Abnormal & $1(1,5)$ \\
\hline
\end{tabular}

Berdasarkan data pada tabel diatas menunjukkan bahwa pada subskala gejala emosional terdapat 35 anak yang memiliki skor normal, 11 anak yang skor borderline, dan 22 anak yang skor abnormal. Pada subskala masalah perilaku terdapat 54 anak yang berada pada kategori normal, 10 anak kategori borderline, dan 4 anak kategori abnormal. Pada subskala hiperaktivitas terdapat 46 anak yang mempunyai skor normal, 16 anak yang skor borderline, dan 6 anak yang skor abnormal. Pada subskala masalah hubungan dengan teman sebaya terdapat 57 anak dalam kategori normal, 10 anak kategori borderline, dan 1 anak kategori abnormal. Dimana diantara semua subskala dalam total skor kesulitan, proporsi anak yang mempunyai skor abnormal dengan masalah gejala emosional merupakan yang terbesar yaitu sebanyak $32,4 \%$.

\section{Pembahasan}

Berbagai stresor psikososial seringkali berhubungan dengan adanya masalah emosi dan perilaku pada anak dan remaja, seperti terdapat penyakit fisik, pola asuh yang inadekuat, kekerasan dalam rumah tangga, hubungan dengan teman sebaya yang inadekuat, serta kemiskinan yang dapat mempengaruhi proses perkembangan kognitif anak sehingga anak lebih memandang negatif lingkungan sekitar dan juga persepsi yang negatif mengenai dirinya. Stresor psikososial juga berkaitan dengan peningkatan emosi negatif, perilaku disruptif dan impulsif, serta menimbulkan cara-cara interaksi yang negatif. ${ }^{38}$

Berdasarkan hasil penelitian, didapatkan bahwa di SMA Negeri 78 Jakarta yang merupakan salah satu sekolah unggulan, terdapat 5 siswa yang berada pada kategori borderline untuk skor kekuatan, yang didapatkan dari subskala perilaku prososial. Dimana siswa seringkali sulit untuk berusaha bersikap baik kepada orang lain, peduli terhadap perasaan sesama, berbagi dengan orang lain, menolong orang yang membutuhkan bantuan, bersikap baik terhadap anak-anak yang berusia lebih muda darinya, dan menawarkan diri untuk membantu orangtua, guru, serta anak-anak.

Terdapat pula 28 siswa yang skor kesulitannya cukup tinggi sehingga berada pada kategori borderline dan abnormal, yaitu 14 siswa merupakan borderline dan 14 siswa masuk dalam kategori abnormal. Dimana total skor kesulitan itu sendiri didapatkan berdasarkan jumlah berbagai subskala yaitu subskala gejala emosional, perilaku menganggu, hiperaktivitas, dan masalah hubungan dengan teman sebaya.

Masalah mental emosional dapat dilihat dari total skor kesulitan, dimana yang terbanyak dialami oleh siswa kelas XI SMA Negeri 78 Jakarta adalah gejala emosional, yaitu sebanyak 22 anak $(32,4 \%)$ berada pada kategori abnormal. Dimana siswa sering mengeluh sakit kepala, sakit perut, atau sakit lainnya yang tidak berkaitan dengan masalah kesehatan fisik, banyak merasa cemas atau khawatir, sering merasa tidak bahagia, sedih, atau menangis, merasa gugup dalam situasi baru, mudah kehilangan rasa percaya diri, sering merasa ketakutan, dan mudah menjadi takut terhadap sesuatu. Sedangkan untuk subskala lainnya terdapat perbedaan yang cukup jauh, dimana hanya ada 6 anak $(8,9 \%)$ pada hiperaktivitas, 4 anak (5,9\%) pada masalah perilaku, dan 1 anak (1,5\%) pada masalah hubungan dengan teman sebaya yang mempunyai skor abnormal.

Penelitian yang dilakukan di negara lain, yaitu di Amerika Serikat menunjukkan bahwa siswa di sekolah unggulan yang mengalami kecemasan, depresi, dan gejala somatik (seperti sakit kepala dan sakit perut) adalah sebanyak $20 \% .{ }^{1}$ Berbeda dengan di Hong Kong, siswa yang berprestasi justru tidak menunjukkan adanya gejala gangguan mental emosional dan perilaku, serta memiliki tingkat kepuasan hidup yang lebih tinggi seiring dengan meningkatnya prestasi di sekolah. ${ }^{5}$ 
Berdasarkan telaah dari teori diatas didapatkan bahwa siswa di sekolah unggulan, yang pada umumnya merupakan siswa pintar dan berbakat karena sekolah tersebut mempunyai standarisasi nilai ujian yang tinggi, merupakan suatu kelompok yang juga berpotensi untuk mengalami gangguan mental emosional.

Hasil penelitian yang telah dilakukan pada siswa kelas XI di SMA Negeri 78 Jakarta, mayoritas mempunyai kesehatan mental emosional yang normal, dengan terdapat beberapa siswa yang memiliki masalah kesehatan mental emosional. Didapatkan skor Strengths and Difficulties Questionnaire cukup tinggi, yaitu dari 68 responden terdapat 28 responden $(41 \%)$ yang memiliki skor kesulitan di atas batas normal, yaitu dalam kategori borderline dan abnormal.

\section{Simpulan}

Berdasarkan penelitian dapat disimpulkan bahwa siswa di SMA Negeri 78 Jakarta yang merupakan salah satu sekolah unggulan mayoritas mempunyai kesehatan mental emosional yang normal, dengan terdapat beberapa siswa yang memiliki skor kesulitan borderline dan abnormal dari hasil skor Strengths and Difficulties Questionnaire yang tidak lepas dari adanya peran orangtua, keluarga, teman sebaya, dan lingkungan sekitar mereka seperti orangtua yang bekerja, penghasilan keluarga, status perkawinan orangtua, pola asuh orangtua, urutan kelahiran anak, bullying di sekolah, prestasi yang diraih, jarak sekolah, durasi penggunaan media sosial setiap harinya, serta kendala online learning selama pandemi yang dapat mempengaruhi status mental, emosi, dan perilaku siswa tersebut.

\section{Daftar Pustaka}

1. Luthar SS, Kumar NL. Youth in highachieving schools: challenges to mental health and directions for evidence-based interventions. Dev Psychopathol. 2018; 44158.

2. Luthar SS, Barkin SH, Crossman EJ. I can, therefore i must: fragility in the upper-middle classes. Dev Psychopathol. 2013;25(4 PART 2):1529-49.

3. Luthar SS, Barkin SH. Are affluent youth truly "at risk"? vulnerability and resilience across three diverse samples. Dev Psychopathol. 2012;24(2):429-49.

4. Luthar SS, Small PJ, Ciciolla L. Adolescents from upper middle class communities: substance misuse and addiction across early adulthood. Dev Psychopathol. 2018;30(1):315-35.

5. Shek DTL, Li X. Perceived school performance, life satisfaction, and hopelessness: a 4-year longitudinal study of adolescents in Hong Kong. Soc Indic Res. 2016;126(2):921-34.

6. Wimbarti S, Siregar J, Oktaviana M, Astriningsih R. Strengths and difficulties questionnaire parent report (SDQ-PR) as screening instrument of children mental health in Indonesia. J Psikol. 2019;46(2):130-44.

7. Ogundele MO. Behavioural and emotional disorders in childhood: a brief overview for paediatricians. World $\mathrm{J}$ Clin Pediatr. 2018;7(1):9-26

8. Khan L. Fatherhood: the impact of fathers on children's mental health. Cent Ment Heal. 2017;50:1-14.

9. Suryaputri IY, Rosha BC, Sari K. Gender and other factors and risk of mental emotional problems among students in Indonesia. Heal Sci J Indones. 2013;4(2):98-102

10. Idaiani S, Sapardin AN, Sulistiowati E. Gender, family income, and the risk of mental emotional disorders in selected population. Heal Sci J Indones. 2015;6(1):23-8.

11. Gorostiaga A, Aliri J, Balluerka N, Lameirinhas J. Parenting styles and internalizing symptoms in adolescence: A systematic literature review. Int J Environ Res Public Health. 2019;16(17).

12. Huang CY, Hsieh YP, Shen ACT, Wei HS, Feng JY, Hwa HL, et al. Relationships between parent-reported parenting, childperceived parenting, and children's mental health in Taiwanese children. Int J Environ Res Public Health. 2019;166.

13. Sahithya BR, Manohari SM, Vijaya R. Parenting styles and its impact on children - a cross cultural review with a focus on India. Ment Heal Relig Cult. 2019;22(4):357-83.

14. Khodabakhsh MR, Kiani F, Ahmedbookani S. Psychological well-being and parenting styles as predictors of mental health among students: implication for health promotion. Int J Pediatr. 2014;2(s5)(9):39-46.

15. Liem JH, Cavell EC, Lustig K. The influence of authoritative parenting during adolescence on depressive symptoms in young adulthood: examining the mediating roles of selfdevelopment and peer support. J Genet Psychol. 2010;171(1):73-92.

16. Easey KE, Mars B, Pearson R, Heron J, Gunnel 
D. Association of birth order with adolescent mental health and suicide attempts: a population-based longitudinal study. Eur Child Adolesc Psychiatry. 2019;28(8):1079-86.

17. Bjørngaard JH, Bjerkeset O, Vatten L, Janszky I, Gunnell D, Romundstad P. Maternal age at child birth, birth order, and suicide at a young age: A sibling comparison. Am J Epidemiol. 2013;177(7):638-44.

18. Rostila M, Saarela J, Kawachi I. Birth order and suicide in adulthood: evidence from Swedish population data. Am J Epidemiol. 2014;179(12):1450-7.

19. Risal A, Tharoor H. Birth order and psychopathology. J Fam Med Prim Care. 2012;1(2):137.

20. Hardt J, Weyer L, Dragan M, Laubach W. Anxiety and depression as an effect of birth order or being an only child: results of an internet survey in Poland and Germany. Insights Depress Anxiety. 2017;1(1):015-22.

21. Jeremy TJ, Fisher PA. High achieving students and their experience of the pursuit of academic excellence. ISEP Int Symp. 2012;(April):47599.

22. Schulte Korne G. Mental health problems in a school setting in children and adolescents. Dtsch Arztebl Int. 2016;113:183-90.

23. DeLara EW. Consequences of childhood bullying on mental health and relationships for young adults. J Child Fam Stud. 2018;28:2379-89.

24. Sourander A, Gyllenberg D, Klomek AB, Sillanmäki L, Ilola AM, Kumpulainen K. Association of bullying behavior at 8 years of age and use of specialized services for psychiatric disorders by 29 years of age. JAMA Psychiatry. 2015;73(2):1-7.

25. Pradhan RK, Sinha N. Impact of commuting distance and school timing on sleep of school students. Sleep Biol Rhythms. 2017;15(2):1-6.

26. Getachew B. Factors affecting student's academic performance in ahuntegen general secondary school, North Wollo Zone, Ethiopia. J Educ Learn. 2018;12(2):198-206.

27. Roberts RE, Duong HT. The prospective association between sleep deprivation and depression among adolescents. Sleep. 2014;37(2):239-44.

28. Morgenthaler TI, Hashmi S, Croft JB, Dort L, Heald JL, Mullington J. High school start times and the impact on high school students: what we know, and what we hope to learn. J Clin Sleep Med. 2016;12(12):1681-9.

29. Wheaton AG, Chapman DP, Croft JB. School start times, sleep, behavioral, health, and academic outcomes: a review of the literature. J Sch Heal. 2016;86(5):363-81.

30. Matricciani L, Olds T, Petkov J. In search of lost sleep: secular trends in the sleep time of school-aged children and adolescents. Sleep Med Rev. 2011;203-11.

31. Hou Y, Xiong D, Jiang T, Song L, Wang Q. Social media addiction: its impact, mediation, and intervention. Cyberpsychology J Psychol Res Cybersp. 2019;13(1).

32. Riehm KE, Feder KA, Tormohlen KN, Crum RM, Young AS, Green KM, et al. Associations between time spent using social media and internalizing and externalizing problems among US youth. JAMA Psychiatry. 2019;76(12):1266-73.

33. Hoge E, Bickham D, Cantor J. Digital media, anxiety, and depression in children. Pediatrics. 2017; 140(s2):S76-80.

34. Uhls YT, Ellison NB, Subrahmanyam K. Benefits and costs of social media in adolescence. Pediatrics. 2017;140:S67-70.

35. Huang R, DJ L, N A, JF Y, Zhuang RX, Chang $\mathrm{TW}$, et al. Guidance on active learning at home during educational disruption: promoting student's self-regulation skills in COVID-19 outbreak. UNESCO. 2020.

36. Xiang M, Zhang Z, Kuwahara K. Impact of COVID-19 pandemic on children and adolescents' lifestyle behavior larger than expected. Prog Cardiovasc Dis. 2020;1-8.

37. Fegert JM, Vitiello B, Plener PL, Clemens V. Challenges and burden of the Coronavirus 2019 (COVID-19) pandemic for child and adolescent mental health: a narrative review to highlight clinical and research needs in the acute phase and the long return to normality. Child Adolesc Psychiatry Ment Health. 2020;14(20):1-11.

38. Wiguna T, Manengkei PSK, Rheza AM, Hapsari WA. Masalah emosi dan perilaku pada anak dan remaja di poliklinik jiwa anak dan remaja RSUPN dr.Ciptomangunkusumo (RSCM) Jakarta. Sari Pediatr. 2010;12(4):270-7. 